\title{
SEMANTIC PRIMING STUDY OF RUSSIAN ASPECT AND RESULTATIVITY
}

\author{
OLGA BATIUKOVA, PIER MARCO BERTINETTO, \\ ALESSANDRO LENCI, ALESSANDRA ZARCONE \\ Universidad Autónoma de Madrid, Scuola Normale Superiore di Pisa, \\ Università di Pisa, Universität Stuttgart
}

\section{A B S T RACT}

This paper reports four priming experiments, in which resultative, processual, and delimitative Russian verbs were tested. The experiments were based on the semantic decision task: the participants had to decide whether the target denoted an event / situation with a clear outcome. To assess the impact of morphological cues on the decision latencies, verbs of different morphological complexity (prefixed and unprefixed perfectives) were used. The results obtained suggest that the aspectual feature of resultativity is consistently exploited in semantic priming (processual targets were primed in two experiments), and that the morphological cues facilitate the identification of resultative targets (prefixed perfectives exhibited faster decision latencies than unprefixed perfectives). As far as the delimitative forms are concerned, a category-induction experiment was designed to investigate the subjects' tendency to group them with resultatives or with processuals, since the delimitatives represent an in-between category. The proportion of yes/no answers confirmed that the speakers place the delimitatives between these two domains, but much closer to the processuals than to the resultatives. These findings support the distinction of boundedness vs. telicity from both the theoretical and the behavioural perspective. The fact that the resultative interpretation of the delimitatives was not ruled out completely for most verbs suggests that, when certain conditions are met (when no cognate resultative form is readily available and when the delimitative is frequent enough), the delimitative can be conceptualized as the perfective counterpart of the basic imperfective, thus taking on the prototypical perfective role (resultativity).

\section{[1] INTRODUCTION}

This paper presents an experimental study of the category of verbal aspect and related semantic features in Russian. In particular, we were interested in investigating the relationship between the grammatical (perfective and imperfective) aspect on the one hand, and the aspectual features of resultativity, delimitedness and processuality on the other hand. Psycholinguistic research of aspect 
and event-related categories has begun only recently, and no work has been done on Russian to our knowledge. Many of the existing studies are based on reading tasks, and deal with aspectual coercion (Todorova et al. 2000; Pylkkänen \& McElree 2006; Bott 2008) and the processing of different aspectual classes of predicates (Heyde-Zybatow 2004; Gennari \& Poeppel 2003; Husband et al. ms.). Some of these studies seem to be interested in the inherent complexity of events as ontological categories and do not distinguish between events on the basis of their internal featural constitution (as in Gennari \& Poeppel (2003); Finocchiaro \& Miceli (2002)); others, however, do focus on particular aspectual features or event phases (initial and final boundary achievements in Heyde-Zybatow (2004), durativity and terminativity in Husband et al. (ms.)). The focus on VP that most authors assume is coherent with the compositional approach to aspectual interpretation, but still leaves unanswered the question of what aspectual properties of the verb take part therein and to what extent. This is especially relevant for languages like Russian, which overtly mark their verbal forms for aspect.

One way of proving that a given feature is present in the semantic representation of verb meaning is to show that it is involved in on-line processing effects, such as priming. Semantic priming is defined as "improvement in speed or accuracy to respond to a stimulus [...], when it is preceded by a semantically related stimulus (e.g., cat-dog) relative to when it is preceded by a semantically unrelated stimulus (e.g., table-dog)" (McNamara 2005, 3).

In our study, we followed the semantic priming paradigm to test the feature of resultativity and its interaction with grammatical perfective and imperfective aspect in Russian. The general design is similar to the priming study of resultativity and durativity in Italian (Zarcone 2008; Zarcone \& Lenci 2010), which, in turn, was inspired by the experiment with French data reported in Bonnotte (2008). Both of the previously mentioned studies tested two classes of verbs, non-durative resultatives and durative non-resultatives (achievements and activities in Vendler's terms, respectively). Two semantic decision tasks were performed. In the durativity task, the subjects had to answer whether the target verb denoted a durable situation. In the resultativity task, they had to decide whether the target verb denoted an event with a clear outcome. Both studies detected significant facilitating priming effects, as summarized in Table 1.

Note that in both experiments there are differences between ACHs and ACTs in regard to their sensitivity to event type related priming effects. In the French experiment, ACTs (being +DUR) seemed to be primed in the DUR task and ACHs (being +RES) in the RES task: the conclusion drawn from these data was that "only the positive value of each feature benefited from priming" (+DUR for ACTs and +RES for ACHs). In addition, Bonnotte (2008) points out that DUR shows priming effect with both opposite and similar primes, while RES with similar primes only, and she claims that this suggests a crucial difference between RES being a 


\begin{tabular}{lcccc|cccc}
\hline & \multicolumn{3}{c}{ French: Bonnotte (2008) } & \multicolumn{3}{c}{ Italian: Zarcone (2008) } \\
& \multicolumn{2}{c}{ DUR $^{1}$} & \multicolumn{2}{c}{ RES } & \multicolumn{2}{c}{ Zarcone \& Lenci (2010) } \\
& ACH & ACT & ACH & ACT & ACH & ACT & ACH & ACT \\
\hline & & $*$ & & & $*$ & & $* *$ & \\
opposite & & $*$ & $*$ & & & $* *$ & & \\
similar & & $*$ & $*$ & & & & \\
\hline
\end{tabular}

TABLE 1: Summary of results obtained in previous studies

binary feature and DUR being a continuous feature. In the Italian experiment, by contrast, ACHs were more sensitive to opposite primes and ACTs to similar primes. Zarcone \& Lenci (2010) interpreted this result as a crucial difference between ACHs and ACTs rather than between DUR and RES: the event type features of ACHs are more lexicalized and emerge more clearly in an opposition, whereas those of ACTs are more ductile and prone to being facilitated by a similar (+DUR) context.

\section{[2] THE PRESENT STUDY：AN OVERVIEW}

In the present study, the same semantic decision task was performed on four sets of stimuli. In the four experiments, the subjects had to decide whether the target verb "refers to an event / situation with a clear outcome" ("указывает ли глагол на событие или ситуацию с явно выраженным результатом").

In the first three experiments, perfective resultative (i.e. telic) and imperfective processual (i.e. atelic) verbs were tested both as primes and as targets. ${ }^{2}$ Unprefixed perfectives were used in experiment 1 and prefixed perfectives in experiment 2. In experiment 3, prefixed perfectives primed unprefixed perfectives (see the scheme in (9)). The main goals of the first two experiments were as follows. First, we wanted to check whether the native speakers are able to identify a oneto-one relationship between resultativity and perfectivity on the one hand, and processuality and imperfectivity on the other hand. Second, we wanted to see the priming effect of different types of perfective forms (prefixed vs. unprefixed) on the decision latencies, thus assessing the impact of morphological cues on the decision latencies and accuracy.

[1] The following abbreviations will be used henceforth: DUR - durativity, RES - resultativity, ACH - achievement, ACT - activity.

[2] In the present paper we use the terms "perfective/imperfective" in the sense appropriate to the grammar of any Slavic language, namely with reference to the (morpho-)lexical specification of the verbs. In order to refer to the strictly semantic dimension, we make use of the Vendlerian terminology (telic/atelic, accomplishment, activity, etc.). The terms "processuality" and "resultativity" will be employed as mere synonyms of, respectively, atelic and telic. 
The absence of a priming effect in the second experiment (see subsection [3.5] for details) motivated the decision of conducting yet another test (experiment 3 ) to check whether these results were due to the inefficiency of prefixed forms as primes or to their easy identification as resultative targets. To this end, unprefixed targets from experiment 1 were combined with prefixed primes from experiment 2.

In the fourth experiment, an additional category of perfective verbs was tested, the delimitatives (e.g., porabotat' 'work for a while', poigrat' 'play for a while'). At this point, a brief review of the properties of po-delimitatitives is in order to motivate the design of experiment 4 and to provide a background for the interpretation of the obtained results.

This particular Aktionsart was chosen, among other considerations, because of its productivity in modern Russian and its semantic transparency: it contributes a clearly identifiable actionality meaning to the imperfective base, without modifying its lexical content. In addition, delimitativity is conceptually fairly close to resultativity, the other feature tested in this study.

Delimitatives profile a temporally bounded portion of the event, but without a change of state (Isačenko 1965, 234-238; Maslov 2004a, 32; Maslov 2004b, 404; Padučeva 1996, 145-147; Filip 2000; Mehlig 2006; Tatevosov 2003, among others). In other words, they are bounded, like resultatives, but atelic. The well-known tests of adverbial modification show this (cf. Bertinetto \& Delfitto 2000; De Miguel 1999; Batiukova 2006; Lentovskaya 2007-2008): delimitatives are compatible with the adverbials $<$ do $t>$ 'until $t$ ' (1-a), $<\mathrm{s} t$ do $t>$ 'from $t$ to $t$ ' (2-a), the durative adverbial $<x$ vremja ' 'for $x$ time' (3-a), and are not compatible with the time-frame adverbial <za $x$ vremja > 'in $x$ time' (4-a). The resultative forms in $\left(1-\mathrm{a}^{\prime}\right)-\left(4-\mathrm{a}^{\prime}\right)$ are given for comparison.

a. Oni vmeste porisovali do semi They together PO-paint-PST.PERF.DEL until seven 'They painted together until seven o'clock'

$\mathrm{a}^{\prime}$. * Oni narisovali portret vmeste do semi ${ }^{3}$ They NA-paint-PST.PERF.RES portrait together until seven *`They painted the portrait [=finished the portrait] together until seven'

(2) a. Oni porisovali s dvux do trex They PO-painted-PST.PERF.DEL from two to three 'They were painting from two to three'

$a^{\prime}$. ?Oni narisovali portret s dvux do trex They NA-paint-PST.PERF.RES portrait from two to three

[3] This sentence is only acceptable with the interpretation 'They finished the portrait before seven'. 
?'They painted the portrait [=finished the portrait] from 2 to 3’

(3)
a. Oni porisovali
pjat' minut i ušli

They PO-paint-PST.PERF.DEL five minutes and left-PST.PERF

'They painted for five minutes and left'

$a^{\prime}$. *Oni narisovali portret pjat' minut

They NA-paint-PST.PERF.RES portrait for five minutes

*'They painted the portrait [completely] for five minutes'

(4) a. *Oni porisovali za pjat' minut

They PO-paint-PST.PERF.DEL in five minutes

*'They painted in five minutes'

$a^{\prime}$. Oni narisovali portret za pjat' minut

They NA-paint-PST.PERF.RES portrait in five minutes

'They painted the portrait in five minutes'

Delimitatives are typically compatible with durative adverbials with approximate meaning (časa dva 'for about two hours', minut pjat' 'for about five minutes') and with vague quantifiers (such as nemnogo 'a little'):
On porabotal
časa dva
/ nemnogo i
He PO-work-PST.PERF.DEL for about two hours / a little and ušjol
leave-PST.PERF
'He worked for about two hours and left'

Like all atelic forms, the po-delimitatives do not entail the corresponding telic form:

(6) On popil

čaja, no tak i ne dopil

ego.

He PO-drink-PST.PERF.DEL tea but not DO-drink-PST.PERF.RES it

'He drank some tea, but did not finish it'

As pointed out in several classical as well as recent works (see Isačenko 1965; Dickey 2006; Mehlig 2006), the semantic scope of po-delimitatives extends beyond the prototypical delimitative core, and can be used to express the meanings of other Aktionsarten: most frequently the resultative (7-a) and the distributive (7-b).

(7) a. My \{poeli / pokrasili zabor\} za desjat' minut.

We $\{$ PO-eat / PO-paint the fence $\}$-PST.PERF.RES in ten minutes

'We had lunch / painted the fence in ten minutes'

b. On pobil vsju posudu.

He PO-break-PST.PERF.DISTR all dishes 
'He broke all the dishes'

Because of this potential aspectual ambiguity of the delimitatives, special care was taken in selecting the clearest cases for the data set:

\begin{tabular}{lll}
\hline Verb & Event type of base verb & Transitivity \\
\hline Pobrodit' 'wander a while' & Activity & INTR \\
Podyšat' 'breathe for a while' & Activity & INTR \\
Pogrozit' 'threaten' & Activity & INTR \\
Poigrat' 'play for a while' & Activity / accomplishment & TR / INTR \\
Poiskat' 'search for a while' & Activity & TR \\
Pokrutit' 'twist' & Activity & TR \\
Polistat' 'thumb through the pages of a book' & Activity & TR \\
Popisat' 'write for a while' & Activity / accomplishment & TR / INTR \\
Poplakat' 'cry for a while' & Activity & INTR \\
Porabotat' 'work for a while' & Activity & INTR \\
Poxodit' 'walk for a while' & Activity & INTR \\
Poževat' 'chew for a while' & Activity & TR \\
\hline
\end{tabular}

TABLE 2: Delimitatives selected for experiment 4

Most of these delimitatives are derived from activities (see Padučeva 1996, 145-147), dynamic events implying no change of state. They represent homogeneous or cumulative (in terms of Krifka 1989, 1992) events: any part of the event has the same properties as the whole event (cf. Tatevosov 2003). For instance,

[3] We disregard the stative meaning of grozit' here (as in 'it's threatening to rain'), since it cannot be used to derive the delimitative form.

[4] The transitive use of igrat' 'play' corresponds to the meaning 'to perform a piece of music'.

[5] As an anonymous reviewer points out, correctly, poxodit' has another, lexicalized meaning: 'be similar to'. However, it is less frequent than the delimitative meaning we are interested in, and has a formal, literary flavour to it (out of a total of 3326 hits in the Russian Web Corpus, approximately a third, 1142, corresponds to this lexicalized meaning, which can be easily identifiable since the complement of the verb is introduced by the preposition na). Given that it is almost impossible to avoid polysemy, we consciously chose to keep this kind of verbs. To insure that the corresponding results are not skewed, the subjects were instructed to think of the most extended verb meaning in each case. Anyway, a separate analysis performed on poxodit' showed that there was no significant difference between the decision latencies of this verb as contrasted with the other delimitatives:

\begin{tabular}{lcc}
\hline & Mean $(\mathrm{ms})$ & Standard deviation $(\mathrm{ms})$ \\
\hline Poxodit' & 2276 & 925 \\
Other delimitatives & 2587 & 967 \\
$t(40.4)=-0.66$ & & \\
$p=0.52$ & & \\
\hline
\end{tabular}


any part of the event of crying or looking for something can be defined as 'cry' or 'look for, search', respectively. ${ }^{7}$

The data above also includes two verbs (igrat' 'play' and pisat' 'write'), which can behave as activities when used intransitively or as accomplishments when accompanied by a direct object: igrat' 'play' vs. igrat' simfoniju 'play a symphony'; pisat' 'write' vs. pisat' roman 'write a novel'. Accomplishments are quantized or heterogeneous entities, since the properties of their final subevent (the resultant state of 'having played a symphony' or 'having written a novel') are different from the properties of the activity subevent, 'playing a symphony' or 'writing a novel'. As noted in Bertinetto \& Squartini (1995), among others, "most accomplishments show their true character in allowing for the contextual obliteration of their telicness". This is exactly what happens when a delimitative is derived from an accomplishment base verb: the resultant phase is obliterated, and the delimitative focuses on a temporally bounded quantity of the activity that precedes the change of state (see Mehlig 2007 and Maslov 2004b, 404-405). The fact that the culmination subevent is demoted in this case does not imply that the resultative reading is definitely excluded. Rather, no information is provided as to whether the final goal has been achieved or not. As Mehlig (in press) suggests, "If nevertheless, these predications are as a rule interpreted as denoting a change-ofstate which has not reached the culmination point, then this is a conversational implicature which arises from the non-use of the paired perfective verb". For example, we cannot infer from (8) whether the article was read in its entirety or not, but since a delimitative form was used instead of the resultative pročital 'read through', the implicature is that the reading event was probably not completed.

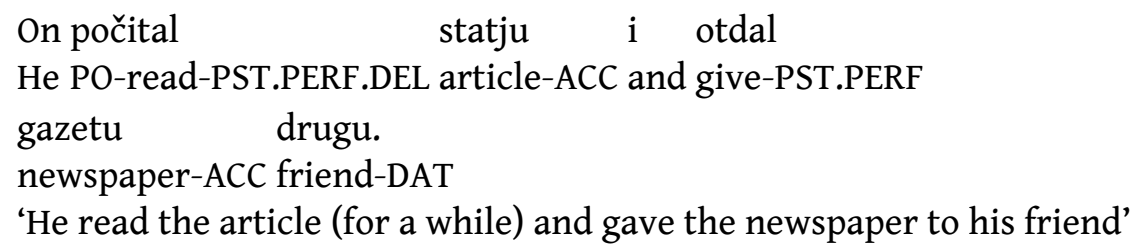

Going back to the design of the fourth experiment, it should be mentioned that it was based on the "category induction" method: participants were shown clearcut resultatives, clear-cut non-resultatives, and delimitatives. For each verb, they had to decide whether it referred to an event / situation with a clear outcome. The relevant measure in this experiment was the proportion of positive and negative answers. The purpose of this experiment was to investigate the subjects'

[7] Tatevosov \& Ivanov (2009, \$5.1.) elaborate on the constraints affecting the distribution of podelimitatives (following Mehlig 2006). They show that the base predicates cannot represent inherently ordered activities, such as shoot the captive or give out a book. Indeed, porasstrelivat' plennogo 'shoot the captive for some time' and povydavat' knigu 'give out a book for some time' are unacceptable with the intended reading. 
tendency to group delimitatives with resultatives or with non-resultatives. As in previous experiments, we were also interested in checking the effect of perfective and imperfective primes on the decision latency in terms of differential speed.

To sum up, the present study aims at providing basic insights into the processing of perfective and imperfective verbal forms of different morphological complexity in Russian. In doing so, it follows feature-based approaches to verbal semantics (commonly assumed in theoretical studies), and focuses on the aspectual feature of resultativity, crucially involved in mechanisms of semantic and syntactic composition (see Dölling et al. 2008, and the references therein). In addition, it aims at pinpointing finer grained (and hence more elusive) details of actionality by focusing on the delimitatives, a category floating between the domains of resultativity and processuality.

\section{[3] METHOD}

\section{[3.1] Participants}

The first three experiments were conducted in Pisa (Laboratorio di Linguistica della Scuola Normale Superiore) and Florence (Università degli Studi di Firenze), and the fourth one in Madrid (Universidad Carlos III). Thirty six native Russian speakers (mostly undergraduate and PhD students) volunteered to participate in each of the experiments and were paid for their collaboration. All had either normal or corrected-to-normal vision.

The participants came from varied professional and academic backgrounds, the only educational requirement was a high school diploma or equivalent. Crucially, none of the subjects had background in theoretical linguistics, which guarantees that their responses were solely guided by their intuitions as native speakers.

\section{[3.2] Materials}

\section{Experiments 1-3}

The stimuli for experiments 1,2 , and 3 were 24 prime-target pairs. Perfective forms in experiment 1 were morphologically simple (unprefixed) ${ }^{8}$ and those in experiment 2 were derived (prefixed). For experiment 3 , we used unprefixed targets from experiment 1 and prefixed primes from experiment 2 . In all experiments, the perfective forms were not related derivationally to the imperfectives.

[8] The set of unprefixed perfectives included suppletive forms (e.g., vzjat', 'take', pojmat' 'catch'), forms with vowel alternation (e.g., brosit' 'to throw', končit' 'to finish') and perfectiva tantum (ruxnut' 'crash, collapse', ucelet' 'survive'). See the Appendix for details. 


\section{a. Experiment 1}

$\begin{array}{llll}\text { PRIMES } & \text { process(IMPERF) } & \text { resultative(UNPREF.PERF) } & \text { neutral (XXX) } \\ \text { TARGETS } & \text { process(IMPERF) } & \text { resultative(UNPREF.PERF) } & \end{array}$

(9)

b. Experiment 2

$\begin{array}{llll}\begin{array}{l}\text { PRIMES } \\ \text { TARGETS }\end{array} & \text { process(IMPERF) } & \text { resultative(PREF.PERF) } & \text { neutral (XXX) } \\ & \text { process(IMPERF) } & \text { resultative(PREF.PERF) } & \\ \text { C. EXperiment } 3 & & \\ & & \\ \begin{array}{l}\text { PRIMES } \\ \text { TARGETS }\end{array} & \text { process(IMPERF) } & \text { resultative(PREF.PERF) } & \text { neutral (XXX) } \\ & \text { process(IMPERF) } & \text { resultative(UNPREF.PERF) } & \end{array}$

Primes and targets were pair-wise balanced for variables known to affect processing costs: frequency and length. To prevent unintended priming effects, special attention was paid to pair up primes and targets belonging to different semantic classes.

Word frequencies were taken from the Russian Web Corpus, integrated into the Word Sketch Engine. The mean log frequency was 3.4 for imperfectives and prefixed perfectives, and 3.8 for unprefixed perfectives. As expected, a pair-wise comparison through a one-way ANOVA revealed a significant difference between unprefixed perfectives and the other two groups $(F=3.552, p=0.034)$. Given the data sparsity problem in the group of unprefixed perfectives, little could be done to get a more balanced sample. However, as will be shown in the results section, a higher frequency of this group did not result in lower decision latencies as compared to the other groups.

As the prefixed forms are longer than the non-prefixed, an effort was made to reduce the difference as much as possible. In the final data set, the mean length was 6.9 characters for unprefixed forms and 7.5 for the prefixed ones. A oneway ANOVA revealed no significant difference between the three groups tested $(F=0.974, p=0.41)$. In order to control the semantic class variable, all the verbs were tagged with generic semantic labels borrowed partially from WordNet classification of topnodes. Given that the topnodes in WordNet are only a convention adopted to label different verb groups and considering that several classes overlap, the main restriction we imposed on prime and target pairs was that they should not belong to semantically related classes, such as state-emotion-body process, social-communication, change-creation-consumption, motion-contactpossession, and cognition-perception.

A total of six lists were compiled for experiments 1 and 2, and three lists for experiment 3. Each target appeared only once in the same list and was paired with an opposite, similar or neutral prime (a string of Xs). In addition to 24 prime-

[9] A string of ' $\mathrm{X}$ ' ('XXXXX') was used as a neutral prime. The neutral prime provides the base-line for assessing the effect of similar and opposite primes on processing. 
target pairs, each list included 3 warm-up pairs (at the beginning) and 9 pairs of distractors, which were not considered in the data analysis. The distractors were non-resultative perfective forms (of the kind listed in (10)) meant to focus the subjects' attention on the semantic feature of resultativity rather than the perfective grammatical aspect.

(10) a. Ingressives: zaryčat' 'start growling', pobežat' 'start running', voznenavidet' 'start hating'

b. Evolutives: razboltat'sja 'start talking a lot', rassmejat'sja 'burst out laughing', razgoret'sja 'flare up'

c. Attenuative-delimitatives: poprideržat' 'hold a little bit', privrat' 'tell a little lie', podzabyt' 'forget a little'

The lists were structured following the scheme in Table 3:

\begin{tabular}{|c|c|c|c|c|c|}
\hline \multicolumn{2}{|c|}{ A } & \multicolumn{2}{|c|}{ B } & \multicolumn{2}{|c|}{$C$} \\
\hline prime & target & prime & target & prime & target \\
\hline $4 \mathrm{P}$ & $4 \mathrm{P}$ & $4 \mathrm{R}$ & $4 \mathrm{P}$ & XXX & $4 \mathrm{P}$ \\
\hline $4 \mathrm{R}$ & $4 \mathrm{R}$ & $4 \mathrm{P}$ & $4 \mathrm{R}$ & XXX & $4 \mathrm{R}$ \\
\hline 3 DIS & 3 DIS & 3 DIS & 3 DIS & XXX & 3 DIS \\
\hline $\mathrm{XXX}$ & $4 \mathrm{P}$ & $4 \mathrm{P}$ & $4 \mathrm{P}$ & $4 \mathrm{R}$ & $4 \mathrm{P}$ \\
\hline XXX & $4 \mathrm{R}$ & $4 \mathrm{R}$ & $4 \mathrm{R}$ & $4 \mathrm{P}$ & $4 \mathrm{R}$ \\
\hline XXX & 3 DIS & 3 DIS & 3 DIS & 3 DIS & 3 DIS \\
\hline $4 \mathrm{R}$ & $4 \mathrm{P}$ & XXX & $4 \mathrm{P}$ & $4 \mathrm{P}$ & $4 \mathrm{P}$ \\
\hline $4 \mathrm{P}$ & $4 \mathrm{R}$ & XXX & $4 \mathrm{R}$ & $4 \mathrm{R}$ & $4 \mathrm{R}$ \\
\hline 3 DIS & 3 DIS & XXX & 3 DIS & 3 DIS & 3 DIS \\
\hline
\end{tabular}

TABLE 3: (XXX - neutral prime, P - 'processual', R - 'resultative', DIS - 'distractor')

In experiments 1 and 2, lists D, E and F were added. They were formed by randomly reversing the order of primes and targets (the targets from lists A, B and $C$ were used as primes in lists D, E and F, while the primes were used as targets, respectively). This was done in order to have more lists and thus test more items in the target position. In experiment 3, however, there were only three lists, since the prefixed perfectives were only tested as primes and the unprefixed perfectives only as targets.

Each participant was assigned one and only one list, in order to restrain the priming effect to one element within each items pair. The presence of neutral primes makes the third (and, in experiments 1-2, the sixth) list necessary. 


\section{Experiment 4}

The stimuli in experiment 4 were 36 prime-target pairs. The data set was composed of 24 imperfectives (the same primes and targets as in experiment 1 ), 12 unprefixed perfectives (the same targets as in experiment 3), 12 prefixed perfectives (the same primes as in experiment 3), and 12 po-delimitatives.

Since the delimitatives are longer and less frequent than the other groups tested (the mean length is 8.6 characters and the mean log frequency 2.85), it was not possible to balance the data set for these two parameters. However, the length and frequency factor was not important in this particular experiment since the relevant measure was the proportion of yes/no answers in the resultativity decision task. Nevertheless, as we wanted to check whether there would be any priming effect (in spite of these between-group differences), the prime and target in each pair were matched for frequency and length. Also for this experiment, we made sure that, within each pair, prime and target belonged to different semantic classes.

A total of three lists were compiled. Since the number of verb pairs per list was higher in this experiment, the number of distractors was reduced to six pairs.

The lists were structured following the scheme in Table 4 :

\begin{tabular}{ll|ll|ll}
\hline \multicolumn{2}{c}{ A } & \multicolumn{2}{c}{$\mathrm{B}$} & \multicolumn{2}{c}{$\mathrm{C}$} \\
\hline prime & target & prime & target & prime & target \\
\hline $4 \mathrm{P}$ & $4 \mathrm{P}$ & $4 \mathrm{R}$ & $4 \mathrm{P}$ & $\mathrm{XXX}$ & $4 \mathrm{P}$ \\
$4 \mathrm{R}$ & $4 \mathrm{R}$ & $4 \mathrm{P}$ & $4 \mathrm{R}$ & $\mathrm{XXX}$ & $4 \mathrm{R}$ \\
$4 \mathrm{R}$ & $4 \mathrm{D}$ & $4 \mathrm{P}$ & $4 \mathrm{D}$ & $\mathrm{XXX}$ & $4 \mathrm{D}$ \\
$2 \mathrm{DIS}$ & $2 \mathrm{DIS}$ & $2 \mathrm{DIS}$ & $2 \mathrm{DIS}$ & $\mathrm{XXX}$ & $2 \mathrm{DIS}$ \\
\hline $\mathrm{XXX}$ & $4 \mathrm{P}$ & $4 \mathrm{P}$ & $4 \mathrm{P}$ & $4 \mathrm{R}$ & $4 \mathrm{P}$ \\
$\mathrm{XXX}$ & $4 \mathrm{R}$ & $4 \mathrm{R}$ & $4 \mathrm{R}$ & $4 \mathrm{P}$ & $4 \mathrm{R}$ \\
$\mathrm{XXX}$ & $4 \mathrm{D}$ & $4 \mathrm{R}$ & $4 \mathrm{D}$ & $4 \mathrm{P}$ & $4 \mathrm{D}$ \\
$\mathrm{XXX}$ & $2 \mathrm{DIS}$ & $2 \mathrm{DIS}$ & $2 \mathrm{DIS}$ & $2 \mathrm{DIS}$ & $2 \mathrm{DIS}$ \\
\hline $4 \mathrm{R}$ & $4 \mathrm{P}$ & $\mathrm{XXX}$ & $4 \mathrm{P}$ & $4 \mathrm{P}$ & $4 \mathrm{P}$ \\
$4 \mathrm{P}$ & $4 \mathrm{R}$ & $\mathrm{XXX}$ & $4 \mathrm{R}$ & $4 \mathrm{R}$ & $4 \mathrm{R}$ \\
$4 \mathrm{P}$ & $4 \mathrm{D}$ & $\mathrm{XXX}$ & $4 \mathrm{D}$ & $4 \mathrm{R}$ & $4 \mathrm{D}$ \\
$2 \mathrm{DIS}$ & $2 \mathrm{DIS}$ & $\mathrm{XXX}$ & $2 \mathrm{DIS}$ & $2 \mathrm{DIS}$ & $2 \mathrm{DIS}$ \\
\hline
\end{tabular}

TABLE 4: Structure of the lists in experiment 4 (D - 'delimitative') 


\section{[3.3] Procedure}

The participants were tested individually using the Presentation experimental software. Each trial was structured as follows: a fixation point ' + ' was displayed in the center of the screen for $600 \mathrm{~ms}$, followed by the prime for $250 \mathrm{~ms}$ and the target for $5000 \mathrm{~ms}$. The stimuli were presented in white lower-case letters on a black background ${ }^{10}$.

During the instruction phase, participants were shown illustrative examples of resultative and non-resultative verbs with two diagrams representing these aspectual classes (as in (11)). No specific linguistic criteria were provided at this point. When introducing the examples, the subjects' attention was drawn to the differences between the two diagrams: crucially, the presence of a double vertical bar symbolizing result at the end of the dashed line for resultative events.
a. resultative events:
e.g.: postroit' 'build', uvidet' 'see, catch sight of', odolet' 'overcome, prevail over', skazat' 'say', razbit' 'break'
b. non-resultative events:
e.g.: zaprygat' 'start jumping', rabotat' 'work', radovat'sja 'be glad, hap- py', poxrapyvat' 'snore a little'

Special emphasis was put on the fact that resultativity and perfectivity overlap only partially: ingressive forms such as zaprygat' 'start jumping' and others were provided to show this point. Finally, participants were instructed to read and identify the first letter string, and to decide as quickly and accurately as possible "whether the second letter string referred to an event or a situation with a clear outcome" ("указывает ли глагол на событие или ситуацию с явно выраженным результатом") ${ }^{11}$. Upper and lower button of the button box were used to answer. The instruction was completed with a training session, made up of seven trials for the first three experiments and ten trials for the fourth experiment (where it was especially important for the subjects to assimilate the difference between prototypical resultatives and processuals).

Each subject was assigned a list, the order of trials was randomized every time a list was displayed.

[10] The reason for this choice (white characters on a black screen) is self-explaining and is nowadays current practice in this sort of experiments. A white screen is felt as exceedingly fatiguing by the participants, who have to stare at it for quite a long time, practically without interruption. A black screen, instead, is much more relaxing for the eyes. Besides, the sharp contrast white-on-black facilitates the process of character recognition.

[11] No theoretical assumptions hinge on the terms 'event' and 'situation' in this case, they are used as interchangeable synonyms. Besides, it should be emphasized once more that the participants had no training in linguistics, so they could not possibly have any technical meaning of these terms in mind. 


\section{[3.4] Design}

In subsequent analyses, the dependent measures were decision latency and accuracy. The featural value of the target (processual and resultative in the first three experiments plus delimitative in the fourth experiment) and the type of priming context (neutral, similar, opposite) were within-subjects factors.

\section{[3.5] Results}

A logistic regression analysis of errors revealed no effect of the priming context, the featural value, the target or any other factor. It is worth mentioning that the accuracy is noticeably high: the mean is 0.93 (see Table 5). The error rate reported in Zarcone \& Lenci (2010) for a similar task in Italian is higher (0.86). This difference is consistent with the fact that in Russian, unlike in Italian, the distinctions in point are in most cases overtly marked and in any case constitute a prominent grammatical feature.

In all decision latencies reported, trials with wrong responses and outliers were excluded. We excluded data points with z-scores above 2 and under -2 after a z-transformation by participant and by item. The outlier removal process affected $7 \%$ of the data in experiment 1,3 and 4 , and $9 \%$ in experiment 2 . Answers given past the $5000 \mathrm{~ms}$ limit were considered outliers.

\begin{tabular}{lcccc}
\hline & Observations & Errors + outliers & Accuracy & SD accuracy \\
\hline Exp1 & 864 & 54 & 0.94 & 0.24 \\
Exp2 & 864 & 52 & 0.94 & 0.24 \\
Exp3 & 864 & 61 & 0.93 & 0.26 \\
Exp4 & 12 & 118 & 0.9 & 0.32 \\
MEAN & 1296 & & 0.93 & \\
\hline
\end{tabular}

TABLE 5: Error rate

The lowest mean decision latencies were obtained in experiment 2 , where prefixed perfectives were used (see Table 6). The longest decision latencies were yielded by the delimitatives, which may be due to two factors. Firstly, as already mentioned, they are less frequent and longer than the other verbs (mean length: 8.6 characters; mean log frequency: 2.85 ). Secondly, they are cognitively more complex due to their status of an in-between category.

As the data in Table 6 show, in all experiments resultative targets yielded faster decision latencies (with respect to the neutral prime condition) after both opposite and similar primes. This processing advantage was also observed after

[12] The error rate for experiment 4 only includes the processual and resultative targets. The accuracy criterion is not applicable to delimitatives for obvious reasons (see section [3]). 


\begin{tabular}{|c|c|c|c|c|c|c|c|}
\hline & & \multicolumn{2}{|c|}{ Neutral } & \multicolumn{2}{|c|}{ Opposite } & \multicolumn{2}{|c|}{ Similar } \\
\hline & & Mean & SD & Mean & SD & Mean & SD \\
\hline \multirow[t]{3}{*}{ Exp1 } & PRO & 1793.86 & 601.75 & 1692.32 & 533.93 & 1710.10 & 526.12 \\
\hline & RES & 1788.18 & 575.09 & 1673.75 & 611.04 & 1735.69 & 621.08 \\
\hline & MEAN & 1790.92 & 589.91 & 1683.04 & 572.70 & 1722.94 & 574.75 \\
\hline \multirow[t]{3}{*}{ Exp2 } & PRO & 1521.45 & 435.99 & 1545.31 & 509.94 & 1563.70 & 458.53 \\
\hline & RES & 1630.02 & 592.81 & 1591.31 & 589.42 & 1569.61 & 522.72 \\
\hline & MEAN & 1576.82 & 523.69 & 1568.50 & 550.79 & 1566.59 & 489.93 \\
\hline \multirow[t]{3}{*}{ Exp3 } & PRO & 1627.34 & 502.58 & 1472.25 & 454.46 & 1504.89 & 447.23 \\
\hline & RES & 1669.96 & 548.65 & 1637.99 & 560.82 & 1574.84 & 464.74 \\
\hline & MEAN & 1648.46 & 525.32 & 1553.46 & 515.06 & 1539.72 & 456.44 \\
\hline \multirow[t]{4}{*}{ Exp4 } & PRO & 2026.51 & 717.83 & 1927.34 & 811.36 & 2088.06 & 746.00 \\
\hline & RES & 1967.58 & 780.73 & 1899.55 & 732.24 & 1956.30 & 786.63 \\
\hline & DEL & 2610.22 & 967.86 & $\begin{array}{c}2507.83 \\
\text { (PRO) }\end{array}$ & 951.55 & $\begin{array}{c}2607.30 \\
\text { (RES) }\end{array}$ & 973.11 \\
\hline & MEAN & 2201.44 & 881.71 & $\begin{array}{l}1913.45 \\
\text { (without DEL) }\end{array}$ & 768.40 & $\begin{array}{l}2022.18 \\
\text { (without DEL) }\end{array}$ & 768.61 \\
\hline
\end{tabular}

TABLE 6: Mean decision latencies

both types of primes for processual targets in experiment 1 and 3. By contrast, processual targets exhibited an advantage only after opposite primes in experiment 4 and showed no advantage whatsoever in experiment 2. A mixed-effect model on decision latencies showed, however, that the given effects reached significance only for processual targets in experiments 1 and 3 (see Table 7).

The results of experiment 3 , which mirror those in experiment 1 , suggest that the absence of priming effect on resultatives in experiments 1 and 2 was not due to the morphological nature of similar primes (prefixed or unprefixed) or of the targets themselves for that matter. Both types of perfective forms are easily identifiable as resultatives, which may hinder the priming effect. Faster reaction times for prefixed targets (in experiment 2) indicate that morphological cues do facilitate the recognition of these forms, even though they are not as frequent as unprefixed resultatives.

Let us now consider the results of the category induction measure for delimitatives in experiment 4. Out of 414 valid observations, 237 were 'no' and 177 'yes'. This means that the speakers categorize this group as an in-between category, with a clear proclivity towards the processual interpretation.

We searched for a possible influence of the aspectual value of the prime on the class assignment of delimitatives. The analysis was performed with a binomial 


\begin{tabular}{|c|c|c|c|c|c|c|c|}
\hline Estimate & MCMCmean & HPD95lower & HPD95upper & pMCMC & $\operatorname{Pr}(>|t|)$ & Significance & \\
\hline \multicolumn{8}{|c|}{ Experiment $1, \mathrm{PRO}$ targets } \\
\hline (Intercept) & 0.0001 & 9.7597 & 9.6864 & 9.8342 & 9.7628 & 0.0000 & \\
\hline opp & -0.0663 & -0.0647 & -0.1292 & -0.0032 & 0.0490 & 0.0290 & $*$ \\
\hline $\operatorname{sim}$ & -0.0622 & -0.0594 & -0.1202 & 0.0037 & 0.0596 & 0.0393 & $*$ \\
\hline \multicolumn{8}{|c|}{ Experiment 1, RES targets } \\
\hline (Intercept) & 9.7404 & 9.7399 & 9.6603 & 9.8160 & 0.0001 & 0.0000 & \\
\hline opp & -0.0491 & -0.0530 & -0.1161 & 0.0091 & 0.0980 & 0.1070 & \\
\hline $\operatorname{sim}$ & -0.0277 & -0.0302 & -0.0897 & 0.0326 & 0.3376 & 0.3567 & \\
\hline \multicolumn{8}{|c|}{ Experiment 2, PRO targets } \\
\hline (Intercept) & 9.6106 & 9.6076 & 9.5365 & 9.6723 & 0.0001 & 0.0000 & \\
\hline opp & -0.0028 & -0.0018 & -0.0615 & 0.0541 & 0.9544 & 0.9190 & \\
\hline $\operatorname{sim}$ & 0.0128 & 0.0139 & -0.0411 & 0.0728 & 0.6348 & 0.6435 & \\
\hline \multicolumn{8}{|c|}{ Experiment 2, RES targets } \\
\hline (Intercept) & 9.6529 & 9.6513 & 9.5668 & 9.7342 & 0.0001 & 0.0000 & \\
\hline opp & -0.0180 & -0.0189 & -0.0823 & 0.0424 & 0.5644 & 0.5460 & \\
\hline $\operatorname{sim}$ & -0.0364 & -0.0352 & -0.0989 & 0.0259 & 0.2676 & 0.2219 & \\
\hline \multicolumn{8}{|c|}{ Experiment 3, PRO targets } \\
\hline (Intercept) & 9.6686 & 9.6660 & 9.5960 & 9.7324 & 0.0001 & 0.0000 & \\
\hline opp & -0.0915 & -0.0927 & -0.1469 & -0.0393 & 0.0014 & 0.0004 & $* * *$ \\
\hline $\operatorname{sim}$ & -0.0677 & -0.0689 & -0.1215 & -0.0139 & 0.0150 & 0.0094 & $* *$ \\
\hline \multicolumn{8}{|c|}{ Experiment 3, RES targets } \\
\hline (Intercept) & 9.6925 & 9.6881 & 9.5903 & 9.7878 & 0.0001 & 0.0000 & \\
\hline opp & -0.0150 & -0.0166 & -0.0715 & 0.0453 & 0.5760 & 0.5915 & \\
\hline $\operatorname{sim}$ & -0.0363 & -0.0378 & -0.0981 & 0.0190 & 0.1994 & 0.1966 & \\
\hline \multicolumn{8}{|c|}{ Experiment 4, PRO targets } \\
\hline (Intercept) & 9.8842 & 9.8797 & 9.7904 & 9.9610 & 0.0001 & 0.0000 & \\
\hline opp & -0.0543 & -0.0567 & -0.1214 & 0.0095 & 0.0898 & 0.0826 & \\
\hline $\operatorname{sim}$ & 0.0338 & 0.0323 & -0.0300 & 0.1005 & 0.3288 & 0.2701 & \\
\hline \multicolumn{8}{|c|}{ Experiment 4, RES targets } \\
\hline (Intercept) & 9.8466 & 9.8414 & 9.7363 & 9.9387 & 0.0001 & 0.0000 & \\
\hline opp & -0.0403 & -0.0398 & -0.1081 & 0.0279 & 0.2590 & 0.2131 & \\
\hline $\operatorname{sim}$ & -0.0205 & -0.0197 & -0.0898 & 0.0466 & 0.5710 & 0.5253 & \\
\hline \multicolumn{8}{|c|}{ Experiment 4, DEL targets } \\
\hline (Intercept) & 10.1067 & 10.1085 & 10.0103 & 10.1989 & 0.0001 & 0.0000 & \\
\hline primeopp_pro & -0.0399 & -0.0408 & -0.1145 & 0.0330 & 0.2822 & 0.2748 & \\
\hline primeopp_res & -0.0083 & -0.0078 & -0.0782 & 0.0695 & 0.8438 & 0.8189 & \\
\hline
\end{tabular}

TABLE 7: Separate analyses [the table contains the estimated coefficients (Estimate), their Markov Chain Monte Carlo (MCMC) mean, the highest posterior density (HPD) confidence interval, a $p$-value based on MCMC (pMCMC), another $p$-value $\operatorname{Pr}(>|t|)$ based on the $t$-statistics, and the significance levels: $*=p<0.05$ (marginally significant effect); $* *=p<0.01$ (significant effect); $* * *=$ $p<0.001$ (highly significant effect)] 
logistic regression model (cbind $(P R O, R E S) \sim$ prime $+s u b j+v e r b)$ and did not yield any significant effect of the prime on the class assignment.

A further analysis of the individual responses of the subjects was performed to see whether any of them consistently categorized the delimitatives as resultatives or as processuals (i.e. gave the same answer in at least $75 \%$ of the observations). As shown in Table 8, out of twenty subjects who did answer consistently, seven seem to have adopted the resultative strategy and thirteen the processual strategy. This confirms that the subjects tended to place the delimitatives closer to the processuals than to the resultatives.

\begin{tabular}{ccc|ccc|ccc}
\hline Subject & PRO & RES & Subject & PRO & RES & Subject & PRO & RES \\
\hline 1 & 5 & 6 & 13 & 7 & 5 & $\mathbf{2 5}$ & $\mathbf{1}$ & $\mathbf{1 1}$ \\
$\mathbf{2}$ & $\mathbf{3}$ & $\mathbf{9}$ & $\mathbf{1 4}$ & $\mathbf{1 0}$ & $\mathbf{1}$ & 26 & 5 & 6 \\
3 & 5 & 5 & 15 & 5 & 6 & $\mathbf{2 7}$ & $\mathbf{1 0}$ & $\mathbf{1}$ \\
4 & 7 & 5 & $\mathbf{1 6}$ & $\mathbf{8}$ & $\mathbf{1}$ & $\mathbf{2 8}$ & $\mathbf{1 2}$ & $\mathbf{0}$ \\
5 & 6 & 6 & 17 & 5 & 7 & 29 & 5 & 7 \\
$\mathbf{6}$ & $\mathbf{8}$ & $\mathbf{4}$ & 18 & 5 & 7 & 30 & 5 & 6 \\
$\mathbf{7}$ & $\mathbf{4}$ & $\mathbf{8}$ & $\mathbf{1 9}$ & $\mathbf{8}$ & $\mathbf{4}$ & 31 & 6 & 5 \\
$\mathbf{8}$ & $\mathbf{1 0}$ & $\mathbf{2}$ & 20 & 5 & 6 & 32 & 5 & 7 \\
$\mathbf{9}$ & $\mathbf{1}$ & $\mathbf{1 1}$ & $\mathbf{2 1}$ & $\mathbf{1 1}$ & $\mathbf{1}$ & $\mathbf{3 3}$ & $\mathbf{9}$ & $\mathbf{3}$ \\
10 & 7 & 4 & $\mathbf{2 2}$ & $\mathbf{4}$ & $\mathbf{8}$ & $\mathbf{3 4}$ & $\mathbf{1 0}$ & $\mathbf{2}$ \\
$\mathbf{1 1}$ & $\mathbf{1 1}$ & $\mathbf{1}$ & $\mathbf{2 3}$ & $\mathbf{8}$ & $\mathbf{1}$ & $\mathbf{3 5}$ & $\mathbf{1 1}$ & $\mathbf{1}$ \\
$\mathbf{1 2}$ & $\mathbf{4}$ & $\mathbf{8}$ & $\mathbf{2 4}$ & $\mathbf{4}$ & $\mathbf{8}$ & 36 & 7 & 4 \\
\hline
\end{tabular}

TABLE 8: Proportion of PRO / RES answers per subject

Performing a qualitative analysis on such a reduced data set is fairly problematic. We can only offer some tentative generalizations about the aspectual and, more broadly, semantic properties of particular verbs and about how these properties might have determined the choice of the speakers.

\begin{tabular}{llllll}
\hline Verb & PRO RES & Verb & PRO RES \\
\hline Pobrodit' 'wander a while' & 18 & 16 & Polistat' 'thumb' & 23 & 13 \\
Podyšat' 'breathe for a while' & 20 & 16 & Popisat' 'write for a while' & 20 & 11 \\
Pogrozit' 'threaten' & 14 & 17 & Poplakat' 'cry for a while' & 15 & 21 \\
Poigrat' 'play for a while' & 18 & 17 & Porabotat' 'work for a while' & 20 & 15 \\
Poiskat' 'search for a while' & 27 & 9 & Poxodit' 'walk for a while' & 24 & 11 \\
Pokrutit' 'twist' & 19 & 15 & Poževat' 'chew for a while' & 19 & 16 \\
\hline
\end{tabular}


Based on the summary in Table 9, three groups of delimitatives can be distinguished according to how they were categorized by the participants:

1) verbs preferably categorized as processuals: poiskat' 'search for a while', popisat' 'write for a while', poxodit' 'walk for a while', and polistat' 'thumb through the pages of a book'

2) verb preferably categorized as resultative: poplakat' 'cry for a while'

3) verbs categorized as either processual or resultative in comparable degree: pobrodit' 'wander for a while', podyšat' 'breathe for a while', poigrat' 'play for a while', pokrutit' 'twist', porabotat' 'work for a while', poževat' 'chew for a while', and pogrozit' 'threaten'

The base verb of popisat' 'write for a while', in group 1, can behave as either an activity or an accomplishment, the latter interpretation being associated with the resultative form napisat' 'finish writing, create by writing'. The sharp contrast between these two forms (the resultative and the delimitative) might have motivated the speakers' choice, even though generally delimitative forms derived from accomplishments do not exclude a resultative interpretation (see section [2]). However, the same account cannot be straightforwardly applied to the other verbs in the same group: poiskat' 'search for a while', poxodit' 'walk for a while', and polistat' 'thumb through the pages of a book' are derived from homogeneous events (activities), which do not imply any kind of result or culmination, and are not coupled with any perfective verb with this meaning. We believe that in this case other perfective forms conventionally associated with the base verb might have come into play, suggesting a completed view in one way or another. In other words, the existence of a cognitively prominent resultative counterpart ${ }^{14}$ might have blocked the possible resultative interpretation of the delimitative. Indeed, polistat' 'thumb through the pages of a book' can only indirectly be related to the terminative form prolistat' 'thumb through (the whole book)'. The same effect could explain the case of poxodit' 'walk for a while', a non-directed motion verb associated with the perdurative form proxodit' 'walk for a certain period of time', and with the many perfective forms derived from the corresponding directed motion verb idti 'go somewhere': dojti 'reach some place', projti 'cover a certain distance', etc. The result of iskat' 'search for a while', in turn, is lexicalized as na-

[13] The number of responses per verb varies since wrong answers and outliers were excluded from the analysis, as explained in the beginning of this section.

[14] When talking about 'cognitively prominent resultative counterparts' of delimitatives, we do not imply that such perfectives form aspectual pairs - in the sense traditionally assumed in Slavic aspectology - with the delimitatives (or the corresponding imperfectives, for that matter). We rather refer to the existence of a verbal cluster, in the sense of Janda (2008). See also, among others, Isačenko (1965, 309$339)$ and Batiukova (2006, ch. 4). 
jti 'find', and this strong association prevents poiskat' from being categorized as resultative.

In addition to the above presented semantic and grammatical considerations, a trivial quantitative difference in frequency can explain why some perfective forms are able to block the resultative interpretation of delimitatives while others are not. As mentioned above, resultatives are much more frequent than delimitatives (see the Appendix and Table 10 below); this explains at least in part why they can successfully block the resultative interpretation of the delimitatives. By contrast, other productive Aktionsarten encoding completed events (terminative, perdurative, and finite) usually exhibit lower frequency than the delimitatives. Hence, they are less likely to compete with the delimitatives for the resultative reading.

Verbs that were not unequivocally categorized as either processual or resultative are the largest group (group 3). They denote, again, activity predicates which do not convey any specific goal or result and are not related to any resultative form with the same meaning: pobrodit ' 'wander for a while', podyšat' 'breathe for a while', pokrutit' 'twist', poževat' 'chew for a while', pogrozit' 'threaten', and porabotat' 'work for a while'. Even though a number of perfective Aktionsarten can be derived from their base verbs, apparently none of them is close enough to resultativity to completely exclude the resultative reading of the delimitative form. In some cases this interpretation can even prevail: pogrozit' 'threaten' was identified as resultative in over $50 \%$ of the instances. With poplakat' 'cry for a while' (the only verb in group 2), this effect was even stronger.

Once again, we have to refer to frequency data to complete the analysis for this group. Non-resultative perfective forms potentially capable of expressing the resultative meaning are less frequent than the delimitatives and hence unable to block this interpretation. This even happens when the other perfective forms are closer to resultativity than the delimitative (for example, proževat' 'masticate thoroughly' and sževat' 'chew up', derived from ževat' 'chew').

The Table 10 on the facing page summarizes the frequency data of delimitatives and cognate perfective forms.

To sum up, we can conclude that the processual interpretation of the delimitatives was preferred over the resultative interpretation, which confirms that the notions of telicity and boundedness should be kept apart. However, these forms were sometimes categorized as resultatives for both typically homogeneous and tendentially heterogeneous predicates. For the latter, this is a logical consequence of the fact that the resultative interpretation is not completely ruled out. As for typically homogeneous predicates lacking any directly cognate resultative form, the delimitatives can sometimes take on the resultative interpretation when other related non-resultative perfective forms are not close enough to resultativity or else are less frequent than the delimitative. 


\begin{tabular}{|c|c|c|c|c|c|c|c|c|}
\hline Delimitative & $\begin{array}{l}\text { PRO/RES } \\
\text { an- } \\
\text { swers }\end{array}$ & LF & Resultative & LF & Perdurative & LF & $\begin{array}{l}\text { Other perf. } \\
\text { forms }\end{array}$ & LF \\
\hline \multicolumn{9}{|c|}{ Group 1} \\
\hline $\begin{array}{l}\text { Poiskat' } \\
\text { 'search for a while' }\end{array}$ & $27 / 9$ & 3.38 & & & $\begin{array}{l}\text { Proiskat' } \\
\text { 'search for a certain } \\
\text { period of time' }\end{array}$ & 0.85 & $\begin{array}{l}\text { Najti } \\
\text { 'find' }\end{array}$ & 4.85 \\
\hline Popisat' & $20 / 11$ & 2.59 & Napisat' & 4.77 & & & & \\
\hline 'write for a while' & & & $\begin{array}{l}\text { 'finish writing, } \\
\text { create by writing' }\end{array}$ & & & & & \\
\hline \multirow[t]{5}{*}{$\begin{array}{l}\text { Poxodit' } \\
\text { 'walk for a while' }\end{array}$} & $24 / 11$ & 2.92 & & & $\begin{array}{l}\text { Proxodit' } \\
\text { 'walk for a certain } \\
\text { period of time' }\end{array}$ & 4.66 & $\begin{array}{l}\text { Sxodit' } \\
\text { 'go somewhere and } \\
\text { back' SEM }\end{array}$ & 3.99 \\
\hline & & & & & & & Dojti & 4.06 \\
\hline & & & & & & & 'reach some place' & \\
\hline & & & & & & & Projti & 4.74 \\
\hline & & & & & & & 'cover a distance' & \\
\hline $\begin{array}{l}\text { Polistat' } \\
\text { 'thumb' }\end{array}$ & $23 / 13$ & 2.56 & & & & & $\begin{array}{l}\text { Prolistat' } \\
\text { 'thumb through (the } \\
\text { whole book)' TERM }\end{array}$ & 2.25 \\
\hline \multicolumn{9}{|c|}{ Group 2} \\
\hline Poplakat' & $15 / 21$ & 2.57 & & & Proplakat' & 1.99 & & \\
\hline 'cry for a while' & & & & & $\begin{array}{l}\text { 'cry for a certain } \\
\text { period of time' }\end{array}$ & & & \\
\hline \multicolumn{9}{|c|}{ Group 3} \\
\hline $\begin{array}{l}\text { Pobrodit' } \\
\text { 'wander a while' }\end{array}$ & $18 / 16$ & 2.74 & & & $\begin{array}{l}\text { Probrodit' } \\
\text { 'wander for a } \\
\text { certain period of } \\
\text { time' }\end{array}$ & 0.78 & & \\
\hline Podyšat' & $20 / 16$ & 2.75 & & & & & & \\
\hline \multicolumn{9}{|l|}{ 'breathe for a while' } \\
\hline Poigrat' & $18 / 17$ & 3.39 & *Sygrat"15 & 3.92 & Proigrat $^{16}$ & & & \\
\hline 'play for a while' & & & $\begin{array}{l}\text { 'perform a piece of } \\
\text { music', 'play a game' }\end{array}$ & & $\begin{array}{l}\text { 'play for a certain } \\
\text { period of time' }\end{array}$ & & & \\
\hline $\begin{array}{l}\text { Pogrozit' } \\
\text { 'threaten' }\end{array}$ & $14 / 17$ & 2.54 & & & & & & \\
\hline $\begin{array}{l}\text { Pokrutit' } \\
\text { 'twist for a while' }\end{array}$ & $19 / 15$ & 2.76 & $\begin{array}{l}\text { *Skrutit' } \\
\text { 'twist off, 'tie up' }\end{array}$ & 2.68 & & & & \\
\hline $\begin{array}{l}\text { Porabotat' } \\
\text { 'work for a while' }\end{array}$ & $20 / 15$ & 3.46 & & & $\begin{array}{l}\text { Prorabotat' } \\
\text { 'work for a period of } \\
\text { time' }\end{array}$ & 3.16 & $\begin{array}{l}\text { Otrabotat' } \\
\text { 'work for a period of } \\
\text { time, work a shift' } \\
\text { FIN }\end{array}$ & 3.01 \\
\hline $\begin{array}{l}\text { Poževat' } \\
\text { 'chew for a while' }\end{array}$ & $19 / 16$ & 2.54 & $\begin{array}{l}\text { *Sževat' } \\
\text { 'chew up' }\end{array}$ & 1.82 & $\begin{array}{l}\text { Proževat' } \\
\text { 'chew for a period of } \\
\text { time', 'masticate } \\
\text { thoroughly' }\end{array}$ & 1.89 & & \\
\hline
\end{tabular}

TABLE 10: Log frequency of delimitatives and related perfective forms (LF - log frequency; SEM - 'semelfactive', TERM - 'terminative', FIN - 'finite'. As elsewhere in the paper, we only consider the non-lexically-idiosyncratic meanings of the prefixed forms.)

[14] The star '*' is used here to mark resultative forms whose meaning differs from the corresponding imperfective form. Sygrat' is a true resultative for one of the senses of igrat': 'perform (a piece of music)'. Sygrat' corresponding to the other meaning of igrat', 'engage in sport or recreation', has a semelfactive flavor: 'play a game, a match'. Skrutit' has several lexicalized meanings, such as 'wrench off (a screw-bolt)', 'tie up', and 'roll a cigarette'. Sževat' means 'chew up', it is also partially lexicalized.

[15] The most frequent meaning of proigrat' is 'lose (in a match or a game)'. As most instances in the corpus correspond to this sense, it is hard to determine the frequency of the perdurative form. 
These conclusions are consistent with the view of aspectual pairhood and aspectual clustering put forward in Dickey (2006) and Janda (2006). Janda (2006) suggests that Russian verbs sharing the same root form structured clusters and these verbs are represented as clusters in the minds of the speakers (this conception is meant to replace the traditional model based on aspectual pairs). The resultative forms denoting volitional goal-oriented (i.e. resultative) actions are cognitively prominent in a cluster ${ }^{17}$ and hence have higher probabilities of being activated (along with the basic imperfective form) than other perfectives. As Dickey (2006) shows, when an imperfective form has no resultative counterpart (for the situation denoted is inherently homogeneous and atelic, and the result is not lexicalized, as in the case of rabotat' 'work'), the po-delimitative becomes eligible as a neutral (typically resultative) perfective partner. ${ }^{18}$

Alternatively, one can account for the pairhood effects described above, by considering it a kind of grammatical bias or metalinguistic reflex. The Russian speaker expects to find clustered verbs, at least one of which is prototypically telic. When there is no telic form immediately available, the resultativity feature gets extended to an available, less prototypical, form.

\section{[4] GENERAL DISCUSSION AND CONCLUSIONS}

The goal of the present research was to provide basic insight into the processing of perfective and imperfective aspect in Russian by focusing on the resultativity feature.

In general, it was shown that this feature is consistently exploited in semantic priming. This confirms the role it plays in the mental representation of verb meaning. Furthermore, the results showed that semantic processing depends on the featural value of the target: only negatively marked targets (processuals) were affected by priming. This pattern contrasts with the results in Bonnotte (2008), where priming mainly occurred on positively marked targets: ACHs in the RES task and ACTs in the DUR task. It also differs partially from the results in Zarcone \& Lenci (2010), where, in addition to the facilitating effects reported in Bonnotte (2008), ACHs were found to yield priming in the DUR task.

As we mentioned in section [1], both Bonnotte (2008) and Zarcone \& Lenci (2010) put forth a proposal regarding the different strength of the priming effect of resultativity vs. durativity, and activities vs. achievements. Both studies pointed out that activities are more likely to benefit from priming because they are contextually more malleable. According to Bonnotte (2008), the reason for this asymmetry is that durativity is a continuous feature while resultativity a binary one. Zarcone \& Lenci (2010) ascribed this difference to the different lexical

[17] This prominence is explained along the source-goal asymmetry, a general cognitive tendency investigated from the linguistic perspective at least since Lakusta \& Landau (2005).

[18] See Dickey (2007) for a diachronic account of the development of different po-meanings. 
encoding of these two features: "the [+DUR] and [-RES] of ACTs is ductile and subject to contextual adaptation, whereas ACHs are more 'inherently' [-DUR] [+RES]". Since the durativity feature was not tested in our experiments (many resultative forms were durative, and hence positively marked for both [+DUR] and [+RES]), we cannot straightforwardly compare our results to the ones in Bonnotte (2008) and Zarcone \& Lenci (2010) in this respect. However, as far as resultativity is concerned, we did find that non-resultative (atelic) verbs give rise to priming, unlike the resultative (telic) ones, which certainly confirms that atelic verbs are more subject to contextual adaptation. A specific study on durativity would be needed in order to assess its empirical relevance and make far-reaching generalizations on its role in on-line processing effects.

The analysis of decision latencies and the error rate shows that the identification of resultative forms was an easy task for the native speakers, which most certainly has to do with the grammaticalized nature of aspect in Russian. An additional facilitating factor was the morphological cue: prefixed forms were identified faster than unprefixed ones.

The design adopted in this experimental research went beyond the studies it was inspired by, in that not only clear-cut categories were tested but also one in-between category, namely the category of delimitatives, which is atelic (like the processuals) and bounded (like the resultatives). The proportion of positive and negative answers in the category induction experiment suggests that indeed Russian speakers place the delimitatives between these two domains, but much closer to the processuals than to the resultatives. These findings support the distinction of boundedness vs. telicity from both the theoretical and the behavioural perspective (Bertinetto \& Lentovskaya 2012).

Although the group of delimitatives tested was not representative enough to perform a thorough qualitative analysis, our data seem to indicate that, whenever a readily available resultative form is present in the cluster to which the delimitative belongs, the latter is less likely identified as a resultative, even though such reading is not completely ruled out. By contrast, when no such resultative is readily available, the delimitative verb can more easily be conceptualized as the perfective counterpart of the basic imperfective, thus taking on the prototypical perfective role (resultativity). We also pointed out that the probability of the resultative reading of the delimitative depends on whether its frequency is higher than that of the "competing" perfective forms. As a rule, the delimitatives are less frequent than pure resultatives and more frequent than other perfective Aktionsarten. Thus, in most cases, they are successfully blocked by their resultative cognates. Although the frequency factor alone does not account for all facts (for in many cases there are also semantic reasons preventing the delimitatives from taking on the resultative interpretation), it has to be taken into account, given its impact on processing. 
There remain some problematic issues in this study that have not been addressed directly and should be clarified in further research. One of these issues is the absence of priming effect on processuals in experiment 2, although the same primes and targets yielded highly significant priming effect in experiment 3. Note, however, that the situation was not exactly the same in both experiments. In experiment 2, prefixed perfectives were used as both primes and targets, which maximized the morphological contrast between resultatives and processuals and most likely facilitated the recognition of both groups, therefore hindering the priming effect. The same holds for experiment 4 , although in this case the absence of priming could have been caused by the possible confusion induced by delimitatives.

We hope that the results of this first empirical study will contribute to foster the experimental investigation of aspect and actionality in Russian, providing new theoretical insight into the syntax-semantics interface.

\section{AKNOWLEDGEMENT}

We gratefully acknowledge the financial and technical support of Laboratorio di Linguistica (Scuola Normale Superiore di Pisa). Without the invaluable assistance of its staff members (Irene Ricci, Chiara Bertini, and Maddalena Agonigi) none of this would have been possible. We appreciate all the participants from Pisa, Florence, and Madrid, who gave up a part of their scarce spare time to take the tests, and all the colleagues and friends who put their Russian-speaking acquaintances in Italy and Spain at our disposal (Anna Lentovskaya, Francesca Fici Giusti, Svetlana Yaskova, Svetlana Holtsova, Yulia and Sofia Grinevich, Olga Kebko, Anjelika Prokofieva, Maria Kubareva, Olga Oleneva, and so many more). Many thanks to the audience of the "Russian Verb" conference (especially Hans Robert Mehlig, Stephen Dickey, and Atle Grønn), as well as to Elena de Miguel and to an anonymous reviewer of OSLa, for their insightful and encouraging comments on this study. This project has been partially financed by a postdoctoral scholarship and a grant "Juan de la Cierva" awarded to Olga Batiukova by the Ministry of Science and Innovation of Spain, and by the research project "Diccionario electrónico multilingüe de verbos de movimiento con significado amplio (andar, ir, venir y volver)" (FFI2009-12191, Universidad Autónoma de Madrid).

\section{REFERENCES}

Batiukova, O. 2006. From lexicon to syntax: aspect and qualia in the grammar of Russian and Spanish. Madrid: Publicaciones de la Universidad Autónoma de Madrid.

Bertinetto, P.M. \& D. Delfitto. 2000. “Aspect vs. Actionality: Why they should be kept apart”. In Ö. Dahl (ed.), Tense and Aspect in the Languages of Europe, 189-226. Berlin: Mouton de Gruyter. 
Bertinetto, P.M. \& A. Lentovskaya. 2012. "A diachronic view of the actional/aspectual properties of Russian verbs". Russian Linguistics 1(36).

Bertinetto, P.M. \& M. Squartini. 1995. "An attempt at defining the class of gradual completion verbs". In P.M. Bertinetto, V. Bianchi, J. Higginbotham \& M. Squartini (eds.), Temporal Reference, Aspect and Actionality. I: Semantic and Syntactic Perspectives, 11-26. Torino: Rosenberg \& Sellier.

Bonnotte, I. 2008. "The role semantic features in verb processing". Journal of Psycholinguistic Research (37). 199-217.

Bott, O. 2008. "Doing it again and again may be difficult, but it depends on what you are doing". In Proceedings of the 27th WCCFL, Somerville, MA: Cascadilla Press.

De Miguel, E. 1999. “El aspecto léxico”. In I. Bosque \& V. Demonte (eds.), Gramática Descriptiva de la Lengua Española, 2977-3060. Madrid: Espasa.

Dickey, S. 2006. "Aspectual Pairs, Goal Orientation and po-Delimitatives in Russian". Glossos 7.

Dickey, S. 2007. "A prototype account of the development of delimitative po- in Russian". In D. Divjak \& A. Kochańska (eds.), Cognitive Paths into the Slavic Domain, 329-374. Berlin: Mouton de Gruyter.

Dölling, J. et al. 2008. Event Structures in Linguistic Form and Interpretation. Berlin: Walter de Gruyter.

Filip, H. 2000. "The Quantization Puzzle". In C. Tenny \& J. Pustejovsky (eds.), Events as Grammatical Objects, 39-96. Standford: CSLI.

Finocchiaro, C. \& G. Miceli. 2002. "Verb Actionality in Aphasia". Folia Linguistica 3(36). 335-358.

Gennari, S. \& D. Poeppel. 2003. "Processing correlates of lexical semantic complexity". Cognition 1(89). 27-41.

Heyde-Zybatow, T. 2004. "Experimentelle Untersuchungen zur Verbklasse der Achievements". In A. Steube (ed.), Grammatik und Kontext: Zur Interaktion von Syntax, Semantik und Prosodie bei der Informationsstrukturierung (Linguistische Arbeitsberichte 81), 11-32. Universität Leipzig.

Husband, M., L. Stockall \& A. Beretta. ms. "VP-internal event composition”. Michigan State University. 
Isačenko, A. 1965. Grammatičeskij stroj russkogo jazyka v sopostavlenii s slovackim, Morfologija I-II. In Wiener Slavistischer Almanach, vol. Sonderband 59, [The edition quoted is 2003, Moscow, Jazyki slavjanskoj kul'tury].

Janda, L. 2006. "Aspectual clusters of Russian verbs". Studies in Language 3(31). 607-648.

Janda, L. 2008. "Motion Verbs and the Development of Aspect in Russian". ScandoSlavica (54). 179-197.

Krifka, M. 1989. "Nominal Reference, Temporal Constitution and Quantification in Event Semantics". In R. Bartsch, J. van Benthem \& P. van Emde Boas (eds.), Semantics and Contextual Expressions, 75-115. Dordrecht: Foris.

Krifka, M. 1992. “Thematic relations as links between nominal reference and temporal constitution". In I. Sag \& A. Szablocsi (eds.), Lexical Matters, 29-53. Stanford: Center for the Study of Language and Information.

Lakusta, L. \& B. Landau. 2005. "Starting at the end: the importance of goals in spatial language". Cognition (96). 1-33.

Lentovskaya, A. 2007-2008. "Una nuova possibile classificazione azionale dei verbi russi”. Cuaderni del Laboratorio di Linguistica (7). http://linguistica.sns . it/QLL/Quaderni.htm.

Maslov, Ju. 2004a. “Očerki po aspektologii. Ob osnovnyx ponjatijax aspektologii”. In Izbrannye trudy, 23-70. Moscow: Jazyki slavjanskoj kul'tury.

Maslov, Ju. 2004b. “Stat'ji po aspektologii. Universal'nye semantičeskie komponenty v soderžanii grammatičeskoj kategorii soveršennogo / nesoveršennogo vida". In Izbrannye trudy, 396-410. Moscow: Jazyki slavjanskoj kul'tury.

McNamara, T.P. 2005. Semantic priming: perspectives from memory and word recognition. New York: Psychology Press.

Mehlig, H.R. 2006. “Glagol'nyj vid i vtoričnaja gomogenizacija oboznačaemoj situacii posredstvom kvantifikacii: K upotrebleniju delimitativnogo sposoba dejstvija v russkom jazyke" [Verbal aspect and the secondary homogenization of a described situation by means of quantification: Use of the delimitative Aktionsart in Russian]. In Semantika i structura slavjanskogo vida. Sbornik materialov konferencii "Slavjanskij vid i leksikografija" (The semantics and structure of Slavic aspect. Collected papers from the conference "Slavic aspect and lexicography") 5, 235-276. Slavolinguistica. 
Mehlig, H.R. 2007. "Aspect and bounded quantity complements in Russian". In S. Rothstein (ed.), Theoretical and Crosslinguistic Approaches to the Semantics of Aspect, 257-290. Amsterdam / Philadelphia: John Benjamins.

Mehlig, H.R. in press. "Hybrid predicates in Russian". In B. Dvorak \& E. Gorischneva (eds.), Collected Contributions to the 2nd Congress of Slavic Linguistic Society, München: Otto Sagner.

Padučeva, E. 1996. Semantičeskie issledovanija. Moscow: Jazyki russkoj kul'tury.

Pylkkänen, L. \& B. McElree. 2006. “The syntax-semantic interface: On-line composition of sentence meaning". In M. Traxler \& M.A. Gernsbacher (eds.), Handbook of Psycholinguistics, 539-580. New York: Elsevier.

Tatevosov, S. 2003. "A Theory of Slavic Aspect and the Russian Delimitative". In P. Kosta et al. (eds.), Investigations into Formal Slavic Linguistics (FDSL IV), 873-891. Frankfurt am Main: Peter Lang.

Tatevosov, S. \& M. Ivanov. 2009. "Event structure of non-culminating accomplishments". In L. Hogeweg, H. de Hoop \& A. Malchukov (eds.), Cross-linguistic Semantics of Tense, Aspect, and Modality, 83-129. Amsterdam / Philadelphia: John Benjamins.

Todorova, M., K. Straub, W. Badecker \& R. Frank. 2000. “Aspectual coercion and the online computation of sentential aspect". In Proceedings of the 22nd Conference of the Cognitive Science Society, 3-8. Mahwah, NJ: Lawrence Erlbaum Associates.

Zarcone, A. 2008. Empirical correlates of event types. Pisa University MA thesis.

Zarcone, A. \& A. Lenci. 2010. "Priming Effects on Event Types Classification: Effects of Word and Picture Stimuli". In S. Ohlsson \& R. Catrambone (eds.), Proceedings of the $32^{\text {nd }}$ Annual Conference of the Cognitive Science Society, 1886-1891. Austin, TX: Cognitive Science Society. 
A APPENDIX

Imperfective targets in experiment 1 (lists $\mathrm{A}, \mathrm{B}, \mathrm{C}$ ), experiment 2 (lists $\mathrm{A}, \mathrm{B}, \mathrm{C}$ ), experiment 3 , and experiment 4

Imperfective primes in experiment 1 (lists D, E, F) and experiment 2 (lists D, E, F)

\begin{tabular}{|c|c|c|c|c|c|c|c|}
\hline Verbs & Semantic class & Length & LF & Verbs & Semantic class & Length & LF \\
\hline xrapet' 'snore' & body process & 7 & 2.75 & $\begin{array}{l}\text { pečatat' 'print, } \\
\text { type' }\end{array}$ & creation & 8 & 3.55 \\
\hline stradat' 'suffer' & emotion & 8 & 4.00 & $\begin{array}{l}\text { gresti 'pull, } \\
\text { paddle' }\end{array}$ & motion & 6 & 2.81 \\
\hline pomogat' 'help' & social & 8 & 4.59 & trogat' 'touch' & contact & 7 & 3.64 \\
\hline $\begin{array}{l}\text { sočinjat' 'com- } \\
\text { pose, make up' }\end{array}$ & creation & 8 & 3.37 & tratit' 'spend' & consumption & 7 & 3.85 \\
\hline $\begin{array}{l}\text { gasit' 'extin- } \\
\text { guish, } \\
\text { out' }\end{array}$ & change & 6 & 2.94 & lupit' 'hit, peel' & contact & 6 & 2.78 \\
\hline kormit' 'feed' & possession & 7 & 3.86 & glazet' 'stare at' & perception & 5 & 2.76 \\
\hline
\end{tabular}

Imperfective primes in experiment 1 (lists $\mathrm{A}, \mathrm{B}, \mathrm{C}$ ), experiment 2 (lists $\mathrm{A}, \mathrm{B}, \mathrm{C}$ ), experiment 3 , and experiment 4

Imperfective targets in experiment 1 (lists D, E, F) and experiment 2 (lists D, E, F)

\begin{tabular}{|c|c|c|c|c|c|c|c|}
\hline Verbs & Semantic class & Length & LF & Verbs & Semantic class & Length & $\mathrm{LF}$ \\
\hline $\begin{array}{l}\text { toptat' 'tram- } \\
\text { ple' }\end{array}$ & change & 7 & 2.93 & $\begin{array}{l}\text { probovat' 'try, } \\
\text { taste' }\end{array}$ & consumption & 9 & 3.80 \\
\hline $\begin{array}{l}\text { šutit' 'joke, } \\
\text { make fun' }\end{array}$ & communication & 6 & 3.64 & $\begin{array}{l}\text { drožat' 'trem- } \\
\text { ble' }\end{array}$ & body process & 7 & 3.83 \\
\hline $\begin{array}{l}\text { zvonit' 'ring, } \\
\text { call' }\end{array}$ & perception & 7 & 4.17 & platit' 'pay' & possession & 7 & 4.24 \\
\hline $\begin{array}{l}\text { merit' 'mea- } \\
\text { sure' }\end{array}$ & cognition & 6 & 2.85 & $\begin{array}{l}\text { bormotat' 'mut- } \\
\text { ter, mussitate' }\end{array}$ & communication & 9 & 3.42 \\
\hline žarit' 'fry' & change & 6 & 3.06 & kivat' 'nod' & motion & 6 & 3.45 \\
\hline $\begin{array}{l}\text { obedat' 'have } \\
\text { lunch' }\end{array}$ & consumption & 7 & 3.37 & $\begin{array}{l}\text { xlopat' 'clap, } \\
\text { spank' }\end{array}$ & contact & 7 & 3.35 \\
\hline
\end{tabular}


Unprefixed perfective targets in experiment 1 (lists A, B, C), experiment 3 , and experiment 4

\section{Unprefixed perfective primes in experiment 1 (lists D, E, F)}

\begin{tabular}{|c|c|c|c|c|c|c|c|}
\hline Verbs & Semantic class & Length & LF & Verbs & Semantic class & Length & LF \\
\hline ucelet'survive' & state & 7 & 3.32 & udarit' 'hit' & contact & 7 & 3.81 \\
\hline spasti 'save' & social & 6 & 3.80 & $\begin{array}{l}\text { prostit' 'for- } \\
\text { give' }\end{array}$ & social & 8 & 4.10 \\
\hline $\begin{array}{l}\text { otvetit' 're- } \\
\text { spond' }\end{array}$ & communication & 8 & 4.64 & $\begin{array}{l}\text { očutit'sja 'find } \\
\text { oneself' }\end{array}$ & motion & 9 & 3.33 \\
\hline pojmat' 'catch' & possession & 7 & 3.92 & $\begin{array}{l}\text { pustit' 'let, re- } \\
\text { lease' }\end{array}$ & contact & 7 & 3.64 \\
\hline končit' 'finish' & change & 7 & 3.39 & najti 'find' & $\begin{array}{l}\text { cognition, per- } \\
\text { ception }\end{array}$ & 5 & 4.64 \\
\hline sest' 'sit down' & motion & 5 & 4.19 & $\begin{array}{l}\text { usvoit' 'adopt, } \\
\text { assimilate' }\end{array}$ & $\begin{array}{l}\text { cognition, pos- } \\
\text { session }\end{array}$ & 7 & 2.97 \\
\hline
\end{tabular}

Unprefixed perfective primes in experiment 1 (lists A, B, C) Unprefixed perfective targets in experiment 1 (lists D, E, F)

\begin{tabular}{|c|c|c|c|c|c|c|c|}
\hline Verbs & Semantic class & Length & LF & Verbs & Semantic class & Length & LF \\
\hline $\begin{array}{l}\text { očnut'sja } \\
\text { 'regain con- } \\
\text { sciousness' }\end{array}$ & body process & 8 & 3.40 & vstretit' 'meet' & social & 9 & 4.06 \\
\hline posetit' 'visit' & motion & 8 & 3.53 & $\begin{array}{l}\text { ruxnut' 'crash, } \\
\text { collapse' }\end{array}$ & motion & 7 & 3.57 \\
\hline $\begin{array}{l}\text { lišit' 'deprive } \\
\text { of' }\end{array}$ & possession & 6 & 3.28 & kupit' 'buy' & possession & 6 & 4.50 \\
\hline rešit' 'decide' & cognition & 6 & 4.69 & obidet' 'offend' & $\begin{array}{l}\text { social, emo- } \\
\text { tion }\end{array}$ & 7 & 3.24 \\
\hline $\begin{array}{l}\text { isčeznut' 'dis- } \\
\text { appear' }\end{array}$ & change & 9 & 4.11 & brosit' 'throw' & motion & 7 & 4.16 \\
\hline leč' 'lay down' & motion & 4 & 3.84 & oščutit' 'feel' & perception & 7 & 3.52 \\
\hline
\end{tabular}


Prefixed perfective targets in experiment 2 (lists A, B, C)

Prefixed perfective primes in experiment 2 (lists D, E, F)

\begin{tabular}{|c|c|c|c|c|c|c|c|}
\hline Verbs & Semantic class & Length & LF & Verbs & Semantic class & Length & LF \\
\hline $\begin{array}{l}\text { poobeščat' } \\
\text { 'make a } \\
\text { promise' }\end{array}$ & communication & 9 & 3.55 & $\begin{array}{l}\text { posadit' 'sit } \\
\text { down, plant' }\end{array}$ & $\begin{array}{l}\text { motion, cre- } \\
\text { ation }\end{array}$ & 8 & 3.80 \\
\hline $\begin{array}{l}\text { počinit' 'repair, } \\
\text { fix' }\end{array}$ & change & 8 & 2.70 & pomyt' 'wash' & change & 6 & 3.00 \\
\hline $\begin{array}{l}\text { ukolot' 'bite, } \\
\text { sting' }\end{array}$ & contact & 7 & 2.31 & upast' 'fall' & motion & 6 & 4.20 \\
\hline poterjat' 'loose' & possession & 8 & 4.32 & $\begin{array}{ll}\text { poverit' } & \text { 'be- } \\
\text { lieve, } & \text { give } \\
\text { credit' } & \end{array}$ & cognition & 8 & 4.18 \\
\hline $\begin{array}{l}\text { poprosit' 'ask (a } \\
\text { favor)' }\end{array}$ & communication & 9 & 4.28 & $\begin{array}{l}\text { vyrostit' 'grow, } \\
\text { raise' }\end{array}$ & creation & 9 & 2.79 \\
\hline $\begin{array}{l}\text { dopit' 'drink } \\
\text { up' }\end{array}$ & consumption & 6 & 2.75 & $\begin{array}{l}\text { nalit' } \\
\text { (out)' }\end{array}$ & $\begin{array}{l}\text { motion, pos- } \\
\text { session }\end{array}$ & 6 & 3.41 \\
\hline
\end{tabular}

Prefixed perfective primes in experiment 2 (lists A, B, C), experiment 3, and experiment 4

Prefixed perfective targets in experiment 2 (lists D, E, F)

\begin{tabular}{|c|c|c|c|c|c|c|c|}
\hline Verbs & Semantic class & Length & $\mathrm{LF}$ & Verbs & Semantic class & Length & $\mathrm{LF}$ \\
\hline slomat' 'break' & change & 7 & 3.69 & prošipet' 'hiss' & communication & 9 & 2.76 \\
\hline $\begin{array}{l}\text { izbit' 'beat, } \\
\text { bang up' }\end{array}$ & contact & 6 & 2.98 & $\begin{array}{l}\text { sgoret' 'burn } \\
\text { away' }\end{array}$ & change & 7 & 3.32 \\
\hline $\begin{array}{l}\text { vylečit' 'cure, } \\
\text { heal' }\end{array}$ & social & 8 & 2.75 & porvat' 'tear' & change & 7 & 3.34 \\
\hline $\begin{array}{l}\text { pročitat' 'read } \\
\text { through' }\end{array}$ & cognition & 9 & 3.89 & $\begin{array}{l}\text { s"est' 'eat up, } \\
\text { consume' }\end{array}$ & consumption & 6 & 3.67 \\
\hline $\begin{array}{l}\text { pozvat' 'call } \\
\text { smb' }\end{array}$ & communication & 7 & 3.75 & sprjatat' 'hide' & motion & 8 & 3.70 \\
\hline $\begin{array}{l}\text { položit' 'put } \\
\text { down' }\end{array}$ & motion & 8 & 4.10 & poslat' 'send' & motion & 7 & 3.90 \\
\hline
\end{tabular}




\section{Delimitative targets in experiment 4}

\begin{tabular}{|c|c|c|c|c|c|c|c|}
\hline Verbs & Semantic class & Length & LF & Verbs & Semantic class & Length & $\mathrm{LF}$ \\
\hline $\begin{array}{l}\text { pokrutit' 'twist } \\
\text { for a while' }\end{array}$ & contact & 9 & 2.77 & $\begin{array}{l}\text { poigrat' 'play } \\
\text { for a while' }\end{array}$ & social & 8 & 3.39 \\
\hline $\begin{array}{l}\text { polistat' 'leaf, } \\
\text { thumb for a } \\
\text { while' }\end{array}$ & contact & 9 & 2.56 & $\begin{array}{l}\text { poplakat' 'cry, } \\
\text { weep for a } \\
\text { while' }\end{array}$ & emotion & 9 & 2.58 \\
\hline $\begin{array}{l}\text { porabotat' } \\
\text { 'work for a } \\
\text { while' }\end{array}$ & social & 10 & 3.46 & $\begin{array}{l}\text { poiskat' 'search } \\
\text { for a while' }\end{array}$ & perception & 8 & 3.38 \\
\hline $\begin{array}{l}\text { poževat' 'chew } \\
\text { for a while' }\end{array}$ & body process & 8 & 2.54 & $\begin{array}{l}\text { poxodit' 'walk } \\
\text { for a while' }\end{array}$ & motion & 8 & 2.92 \\
\hline $\begin{array}{l}\text { podyšat' } \\
\text { 'breathe } \\
\text { for a while' }\end{array}$ & body process & 8 & 2.75 & $\begin{array}{l}\text { popisat' 'write } \\
\text { for a while' }\end{array}$ & creation & 8 & 2.59 \\
\hline $\begin{array}{l}\text { pobrodit' 'wan- } \\
\text { der' }\end{array}$ & motion & 9 & 2.75 & $\begin{array}{l}\text { pogrozit' } \\
\text { 'threaten for a } \\
\text { while' }\end{array}$ & communication & 9 & 2.54 \\
\hline
\end{tabular}


AUTHOR CONTACT INFORMATION

Olga Batiukova

Filología Española

Universidad Autónoma de Madrid

volha. batsiukova@uam.es

Pier Marco Bertinetto

Scuola Normale Superiore di Pisa

Italy

bertinetto@sns.it

Alessandro Lenci

Dipartimento di Linguistica

via Santa Maria 36

56126 Pisa

Italy

alessandro.lenci@ling . unipi.it

Alessandra Zarcone

Institut für Maschinelle Sprachverarbeitung (IMS)

Universität Stuttgart

Azenbergstraße 12

D-70174 Stuttgart

Germany

alessandra. zarcone@ims . uni-stuttgart.de 